\title{
PENGARUH BRAND PERSONALITY DAN BRAND TRUST TERHADAP KEPUTUSAN PEMBELIAN (Studi Kasus Butik Meccanism)
}

\author{
Fauziah Dewi Mahuda \\ Bisnis dan Manajemen Islam, Sekolah Tinggi Ilmu Ekonomi \\ Islam Tazkia Email : Fauziahdewifufu@gmail.com
}

\begin{abstract}
This research aims to figure out the influence of brand personality and brand trust on purchasing decisions of Meccanism Boutique. The indicators that used to measure the brand personality are sincerity,excitement,competence, and sophistication. The data processing is done through Structural Equation Modeling (SEM) approach with a sample of one hundred respondents. The results showed that there is a positive influence of brand personality on the brand trust, and there is an influence of brand trust on purchasing decisions, and indirect influence of brand personality on purchasing decisions through the brand trust. While directly, the brand personality is not proven to have an effect on purchasing decisions.
\end{abstract}

Keywords : Brand Personality, Brand Trust, and Purchasing Decisions

\section{Pendahuluan}

Pada saat kebangkitan Agama Islam, Busana Muslim menjadi populer di Indonesia. Dahulu hubungan antara Agama Islam dengan politik di Indonesia kurang begitu baik. Mengakibatkan penduduk Indonesia tidak menyukai fanatisme Islam. Oleh karena itu, perempuan yang berbusana muslim dianggap sebagai orang yang fanatik dan berlawanan terhadap Negara Indonesia. Akan tetapi keadaan Agama menjadi lebih terbuka setelah kebangkitan Islam. Sejak saat itu semakin meningkatnya perempuan-perempuan yang berbusana muslim. Ternyata berbusana muslim telah diterima dan dianggap sebagai sesuatu yang biasa oleh masyarakat. Busana muslim menjadi unsur kebudayaan populer di Indonesia, dan industri busana muslim berkembang dengan cepat. (Raleigh, 2004)

Dengan pernyataan tersebut sesuai dengan Firman Allah SWT yang menyatakan bahwa seorang muslimah sudah seharusnya untuk menutup aurat yaitu dengan berpakaian busana Muslim. Sebagaimana seperti yang tertera pada Al-Qur'an yaitu surat Al-A'raf ayat 26: 
Artinya: "Hai anak adam, sesungguhnya kami telah menurunkan kepadamu pakaian untuk menutup auratmu dan pakaian inilah untuk perhiasan. Dan pakaian takwa. Itulah yang paling baik, yang demikian itu adalah sebagian dari tanda-tanda kekuasaan Allah, mudahmudahan mereka selalu ingat".

Perkembangan Industri Fashion di Indonesia tidak lepas dari bisnis busana muslim yang meningkat, Hal ini dibuktikan dengan nilai ekspor pada tahun 2013 yaitu 11,78 Miliar, bahkan pada periode Januari hingga Juli 2014 Senilai 8,47 Miliar US\$, Berdasarkan data Organisasi Konferensi Islam (OKI) saat ini ekspor fashion muslim di Indonesia berada diperingkat ketiga dengan nilai 7,18 Miliar setelah Bangladesh dan Turki. Kemendag (2015). Dari data perkembangan fashion muslim tersebut menunjukkan bahwa terdapat potensi yang sangat besar bagi industri fashion busana muslim, maka diharapkan para designer muslim agar dapat berkompetisi untuk mengembangkan fashion dengan baik yaitu dengan menciptakan produk lokal maupun produk asing.

Hal tersebut sesuai dengan teori yang dipaparkan oleh Green and Keegan, (2008) yang menyatakan bahwa persaingan bisnis semakin ketat yang menunjukkan bahwasanya semakin banyak produk-produk yang dipasarkan dengan berbagai macam kualitas, ukuran, harga, bentuk serta manfaat. Berdasarkan hal tersebut merek menjadi hal yang terpenting dan memiliki fungsi sebagai pembeda dari satu produk dengan produk lainnya serta berfungsi untuk membantu konsumen dalam menemukan suatu produk yang dibutuhkannya.

Persaingan bisnis yang terjadi saat ini yaitu dengan banyaknya brand-brand busana muslim yang semakin banyak bermunculan dari waktu ke waktu dengan berbagai kelebihan produk-produk yang dipasarkan, namun ternyata

Salah satu busana muslim di Indonesia yaitu merek Meccanism yang dibangun oleh Zaskia Adya Mecca, Busana Muslim yang Zaskia Adya Mecca buat merupakan hasil ide kreasi yang unik dibandingkan dengan busana muslim lainnya. Keunikan dari desain yang dibuat oleh Zaskia terlihat dari model dan corak yang mencerminkan kepribadian Zaskia Adya Mecca. Zaskia merancang busana muslim didasarkan pengalaman pribadi dan sesuai dengan aturan syariat Islam dan tidak mengikut gaya busana muslimah pada umumnya. Sehingga Zaskia memiliki ciri khas tersendiri pada busana yang digunakannya ataupun untuk dijual di butik Meccanism. (Ainy, 2015).

Butik Meccanism menawarkan dan memasarkan busana muslim yang sesuai dengan syariat Islam tetapi disamping itu model yang dibuat pada pakaian yang dijualnya tetap stylish, sama halnya dengan pengusaha butik muslim lainnya. Butik Meccanism ini bukan hanya untuk kepentingan bisnis saja akan tetapi seperti yang dikatakan oleh Zaskia Adya Mecca dengan Blog 
pribadinya yang menyatakan bahwa Meccanism ini juga bermisi syiar dan Zaskia ingin semua karyanya membawa kebaikan, pelajaran dan nilai hidup. Dalam memasarkan produknya yaitu melalui toko secara langsung atau butiknya yang terdapat diberbagai kota di Indonesia maupun secara online yaitu melalui Facebook, Twitter, dan Instagram. (Handayani, 2016)

Menurut hasil wawancara yang dilakukan penulis kepada salah satu reseller butik Meccanism menyatakan bahwa produk Meccanism memiliki kualitas bahan yang baik, walaupun produk tersebut memberi harga yang cukup tinggi. Namun, harga tersebut sesuai dengan kualitas produk yang diberikan. Hal itu membuat konsumen produk Meccanism menyukai produk tersebut dibandingkan dengan produk pesaing yang lainnya. Berdasarkan pernyataan tersebut membuat penulis memilih produk Meccanism sebagai penelitian.

Dalam sebuah bisnis tidak hanya dilihat dari kepribadian merek saja (Brand personality), akan tetapi kepercayan konsumen pada sebuah merek memiliki peran penting ketika konsumen ingin memutuskan untuk membeli suatu barang yang dibutuhkannya. Hal ini akan membuat konsumen percaya bahwa merek tersebut memiliki citra positif yang bisa menjadikan sebuah jaminan atas kualitas produk tersebut. Konsumen akan membeli segala produk untuk memenuhi kebutuhannya akan tetapi untuk memilih produk apa yang akan mereka beli dan bagaimana konsumen membuat keputusan tersebut memiliki hubungan yang erat dengan perasaan yang dirasakan oleh konsumen terhadap merek-merek yang ditawarkan. Keputusan kosumen dalam membeli suatu produk merupakan suatu tindakan yang dilakukan oleh seorang konsumen ketika ingin membeli sesuatu yang diinginkan dan dibutuhkan. Dengan demikian, Penerapan brand personality dan brand trust diharapkan mampu mempengaruhi keputusan pembelian konsumen.

Dapat disimpulkan berdasarkan latar belakang tersebut menurut penulis menciptakan sebuah brand personality dan brand trust merupakan hal yang penting dalam sebuah bisnis untuk bisa bertahan dan bersaing dengan perusahaan lainnya, maka penulis tertarik untuk membahas dan meneliti seberapa besar pengaruh brand personality dan brand trust terhadap keputusan pembelian dengan studi kasus butik Meccanism.

\section{Tinjauan Pustaka}

\subsection{Brand (Merek)}

Menurut UU Merek No . 15 Tahun 2001 pasal 1 ayat 1, Brand (Merek) merupakan tanda yang berupa gambar, nama, kata, huruf-huruf, angka-angka, susunan warna, atau kombinasi dari unsur-unsur tersebut yang memiliki daya pembeda dan digunakan dalam kegiatan perdagangan barang atau jasa (Tjiptono, 2011). 


\subsection{Brand Personality ( Kepribadian Merek)}

Brand Personality merupakan tahap perkembangan merek, yang berarti merek yang mencerminkan kepribadian (Rangkuti, 2004). Sedangkan menurut Aaker J.L (1997) yang menyatakan bahwa Brand personality adalah seperangkat karakteristik manusia yang berhubungan dengan merek.

\subsection{Brand Trust (Kepercayaan Merek)}

Kepercayaan pada suatu merek ( Brand Trust ) yaitu kemauan seorang konsumen dalam mempercayai terhadap suatu merek dengan segala resikonya karena adanya harapan yang dijanjikan oleh merek dalam memberikan hasil yang positif untuk konsumen (Lee, 1999). Menurut Rizan (2012) kepercayaan merek (Brand Trust ) merupakan kesediaan konsumen untuk mempercayai suatu merek dengan segala resikonya karena adanya suatu harapan dalam fikiran mereka tentang merek tersebut bahwa akan memberikan hasil yang positif sehingga akan menimbulkan kesetiaan terhadap suatu merek.

\subsection{Periaku Konsumen}

Menurut Keller (2008) mendefinisikan tentang perilaku konsumen sebagai studi yang mempelajari tentang bagaimana individu, kelompok, dan organisasi memilih, membeli menggunakan, dan bagaimana barang, jasa,ide, atau pengalaman untuk bisa memuaskan suatu kebutuhan dan keinginan mereka

\subsection{Keputusan Pembelian Konsumen}

Keputusan Pembelian menurut Keller (2008) merupakan suatu proses kejadian pengenalan masalah kebutuhan, pencarian informasi, evaluasi alternatif, keputusan pembelian dan perilaku pasca pembelian. Keputusan pembelian yang dilakukan oleh konsumen merupakan suatu kegiatan dalam membeli produk yang paling disukai dan yang paling dibutuhkan oleh konsumen (Armstrong, 2008).

\section{Metodologi Penelitian}

\subsection{Objek dan Waktu Penelitian}

Objek pada penelitian ini adalah Butik Meccanism. Dan waktu penelitian dilaksanakan yaitu pada bulan April sampai dengan Juli 2017.

\subsection{Jenis dan Sumber Data}

Jenis penelitian yang digunakan eksplanatori dengan pendekatan kuantitatif. Adapun penelitian eksplanatori menurut Sugiyono (2016) merupakan penelitian yang menjelaskan hubungan kausal antara variabel-variabel yang mempengaruhi hipotesis. Data yang dilakukan 
oleh penulis pada penelitian ini yaitu dilakukan dengan memperoleh data primer. Data primer merupakan hasil tabulasi dari jawaban responden. Data tersebut dikumpulkan dan diolah sendiri oleh peneliti yang diperoleh langsung oleh responden. Data primer didapatkan dengan menggunakan instrumen kuesioner. Kuesioner pada penelitian ini menggunakan pertanyaan tertutup dan terbuka. Dalam penelitian ini adalah hasil pengisian kuesioner oleh responden, yaitu para konsumen Meccanism.

\subsection{Populasi dan Sampel Penelitian}

Populasi merupakan wilayah generalisasi yang terdiri atas : objek /subjek yang mempunyai kualitas dan karakteristik tertentu yang ditetapkan oleh peneliti untuk dipelajari dan kemudian diambil kesimpulannya (Sugiyono,2016). Dalam penelitian ini, populasi yang digunakan adalah seluruh konsumen yang pernah melakukan pembelian di Butik Meccanism. Tidak terdapat data yang pasti mengenai jumlah konsumen yang melakukan pembelian di Meccanism,sehingga perlu pengambilan sample dalam penelitian ini. Sedangkan sample menurut Sugiyono (2016) bagian dari jumlah dan karakteristik yang dimiliki oleh populasi tersebut. Besarnya sampel memiliki peran dalam interprestasi SEM dengan metode estimasi menggunakan Maximum Likehood (ML) minimum diperlukan sampel 100 dan maksimum 200. Ghozali (2008) Responden dalam penelitian ini sebanyak 100 sehingga telah memenuhi syarat untuk dapat estimasi modal dengan menggunakan MaximumLikehood (ML).

\subsection{Metode Pengumpulan Data}

Teknik pengumpulan data yang dilakukan dengan cara memberikan seperangkat pertanyaan atau pernyataan tertulis kepada responden untuk dijawabnya Sugiyono (2016). Dengan skala likert, maka variabel yang akan diukur dijabarkan menjadi indikator variabel. Kemudian indikator tersebut dijadikan sebagai titik tolak untuk menyusun item-item instrument yang dapat berupa pernyataan Sugiyono (2016). Jawaban setiap item instrument yang menggunakan skala likert mempunyai gradasi dari sangat positif sampai sangat negative, yang dapat berupa kata-kata yaitu antara lain:

$\begin{array}{lll}\text { SS } & \text { : Sangat Setuju } & 5 \\ \text { S } & \text { : Setuju } & 4 \\ \text { N } & \text { : Netral } & 3 \\ \text { TS } & \text { : Tidak Setuju } & \\ \text { STS } & \text { : Sangat Tidak Setuju } & 1\end{array}$




\subsection{Definisi Operasional Variabel}

Definisi operasional variabel dapat didasarkan pada satu atau lebih referensi yang disertai dengan alasan pengguna definisi tersebut. Variabel penelitian harus dapat diukur menurut skala ukuran yang lazim digunakan. Oleh karena itu, untuk memberikan gambaran yang lebih detail tentang definisi operasional variabel, maka dapat dijelaskan pada tabel berikut ini :

Tabel 1: Operasional Variabel

\begin{tabular}{|c|c|c|c|}
\hline Variabel & Definisi Variabel & Indikator & Skala \\
\hline $\begin{array}{l}\text { Brand } \\
\text { Personality (X) } \\
\text { (Aaker J. L., } \\
\text { 1997) }\end{array}$ & $\begin{array}{l}\text { Brand Personality merupakan } \\
\text { tahap perkembangan merek, } \\
\text { yang berarti merek yang } \\
\text { mencerminkan kepribadian }\end{array}$ & $\begin{array}{ll}\text { 1. } & \text { Sincerity } \\
\text { 2. } & \text { Excitement } \\
\text { 3. } & \text { Competence } \\
\text { 4. } & \text { Sophistication }\end{array}$ & $1-5$ \\
\hline $\begin{array}{l}\text { Brand Trust }(\mathrm{Y}) \\
\text { (Delgado, 2001) }\end{array}$ & $\begin{array}{l}\text { BrandTrust adalah sebuah } \\
\text { keyakinan ataupun janji yang } \\
\text { diberikan oleh suatu merek } \\
\text { terhadap konsumen untuk bisa } \\
\text { memenuhi semua kepentingan } \\
\text { yang digunakan oleh konsumen. }\end{array}$ & $\begin{array}{ll}\text { 1. } & \text { Brand } \\
\text { Reliabilit } \\
y \\
\text { 2. Brand Intention }\end{array}$ & $1-5$ \\
\hline $\begin{array}{l}\text { Keputusan } \\
\text { Pembelian (Z) } \\
\text { (Kotler, 2004) }\end{array}$ & $\begin{array}{l}\text { Keputusan Pembelian adalah } \\
\text { suatu tindakan yang dilakukan } \\
\text { oleh seorang konsumen ketika } \\
\text { ingin membeli sesuatu yang } \\
\text { diinginkan dan dibutuhkan }\end{array}$ & 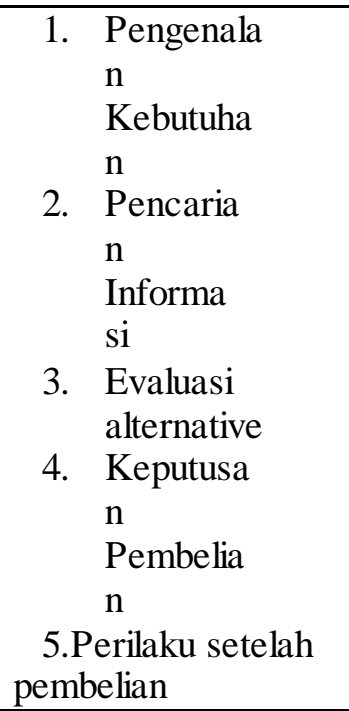 & $1-5$ \\
\hline
\end{tabular}

Sumber: Diolah Dari Penulis 


\subsection{Teknik Analisis Data}

Data dianalisis dan diuji dengan menggunakan teknik multivariate Structural Equation Modeling (SEM) dengan menggunakan program LISREL 8.8 Structural Equation Modeling (SEM) yaitu merupakan suatu teknik statistik yang mampu menganalisis variabel laten, variabel teramati, dan kesalahan pengukuran secara langsung. SEM mampu menganalisis hubungan antara variabel laten yang satu dengan variabel laten yang lain, dan juga untuk mengetahui besarnya kesalahan pengukuran Wijanto (2008). dapat disimpulkan bahwa SEM merupakan suatu teknik statistik yang dapat menganalisis variabel laten dan mengetahui besarnya kesalahan pengukuran. Berdasarkan hasil observasi, pada penelitian ini spesifikasi model dari variabel laten sebagai berikut :

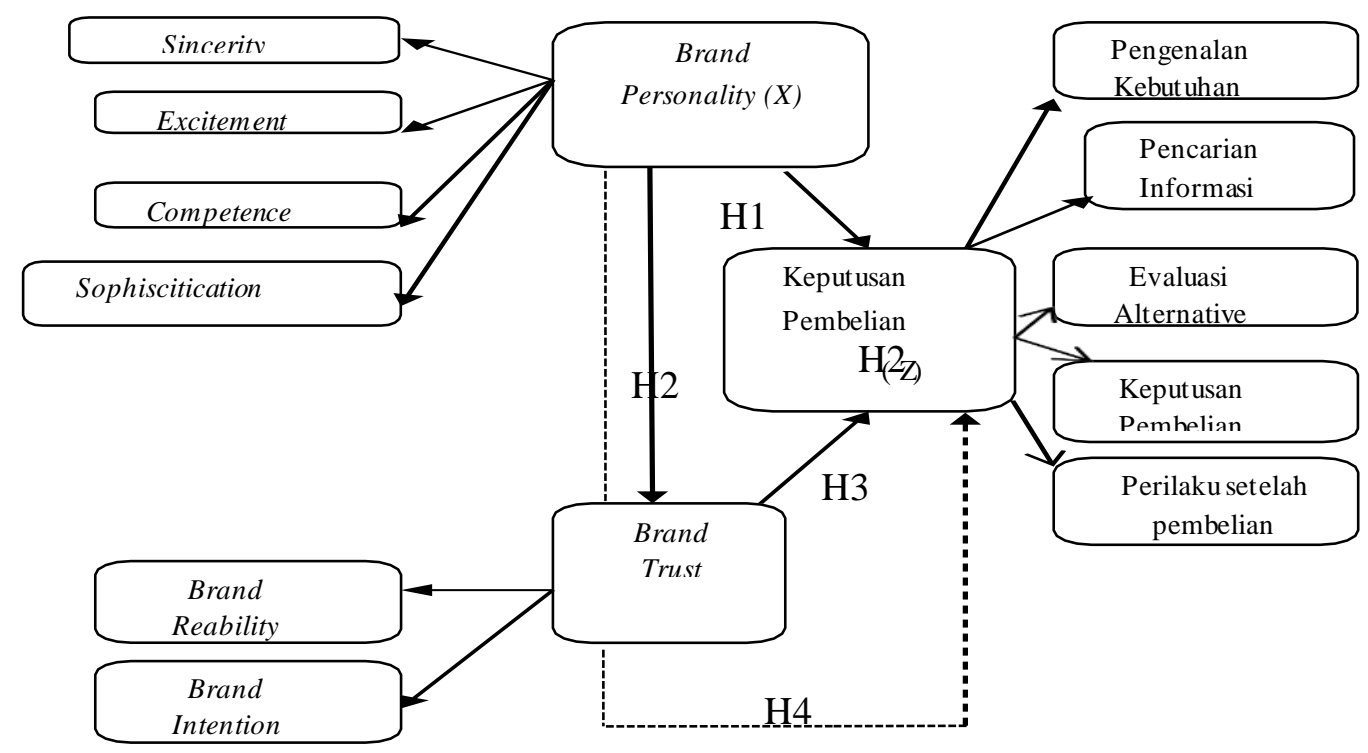

Gambar 1: Spesifikasi Model

Sumber : Diolah Oleh Penulis

\subsection{Model Pengukuran}

1. Evaluasi terhadap validitas (validity) model pengukuran. Validitas berhubungan dengan apakah suatu variabel mengukur apa yang seharusnya diukur. Suatu variabel dikatakan mempunyai validitas yang baik terhadap variabel latennya, jika :

a. Nilai $\mathrm{t}$ muatan faktornya (loadings factor) lebih besar dari nilai kritis $\geq$ 
1,96 dengan tingkat signifikansi statistik lima persen (5\%).

b. Muatan faktor standarnya (standardized loadings factor) $\geq 0,30$

Hair, et al \& Wijanto (2008), atau $\geq 0,50$ (Wijanto, 2008)

2. Evaluasi terhadap reliabilitas (reliability) model pengukuran. Reliabilitas adalah konsistensi suatu pengukuran. Reliabilitas tinggi menunjukkan bahwa indikatorindikator mempunyai konsistensi tinggi dalam mengukur variabel laten. Reliabilitas model pengukuran yang baik, jika :

a. Nilai construct reliability-nya $\geq 0,70$

b. Nilai variance extracted-nya $\geq 0,50$

\section{Hasil Dan Pembahasan}

\subsection{Perilaku Responden}

Berikut adalah hasil kuesioner yang sudah peneliti bagikan kepada para pelanggan Butik Meccanism. Berikut adalah penjelasan dari hasil jawaban responden menurut perilaku responden

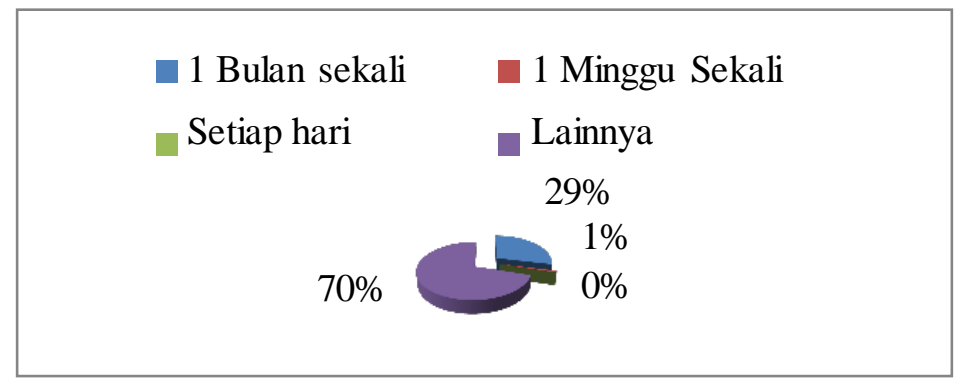

Gambar 2: Frekuensi Responden Seberapa Sering Membeli Produk Meccanism Sumber: Olahan Data Peneliti

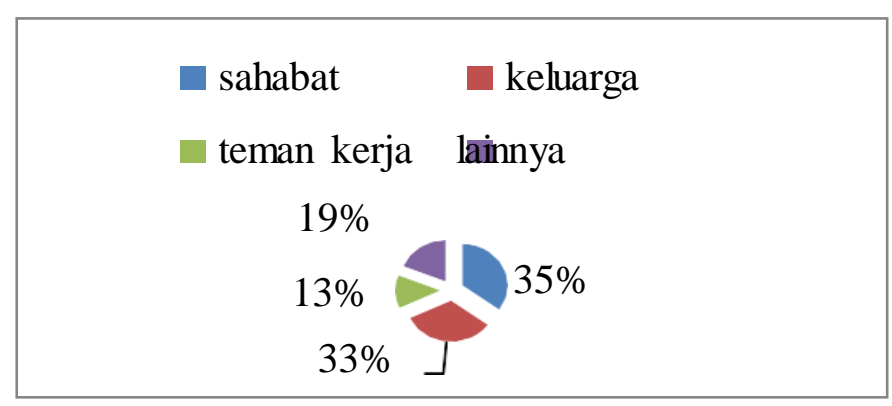

Gambar 2: Perilaku Responden Berdasarkan Dengan Siapa Responden Mengunjungi Butik Meccanism

Sumber: Olahan Data Peneliti 
Menurut gambar 3 di atas, menjelaskan bahwa perilaku resonden Butik Meccanism berdasarkan dengan siapa responden mengunjungi Butik Meccanism. Hasil terbanyak ternyata responden mengunjungi Butik Meccanism bersama sahabat yaitu dengan nilai $35 \%$, dikarenakan kemungkinan ketika bersama sahabat merasa nyaman, dan bisa saling meminta pendapat untuk masalah kecocokan atau tidaknya dalam memakai produk tersebut dan lain sebagainya. Terbanyak selanjutnya yaitu responden mengunjungi Butik Meccanism bersama keluarga dengan nilai sebesar 33\%. Peringkat terbanyak selanjutnya yaitu responden mengunjungi Butik Meccanism lainnya dengan nilai sebesar 19\%. Peringkat terbanyak selanjutnya yaitu responden mengunjungi Butik Meccanism bersama teman kerja dengan nilai sebesar 13\%. Dari hasil diatas peneliti menyimpulkan bahwa responden mengunjungi Butik Meccanism bersama sahabat.

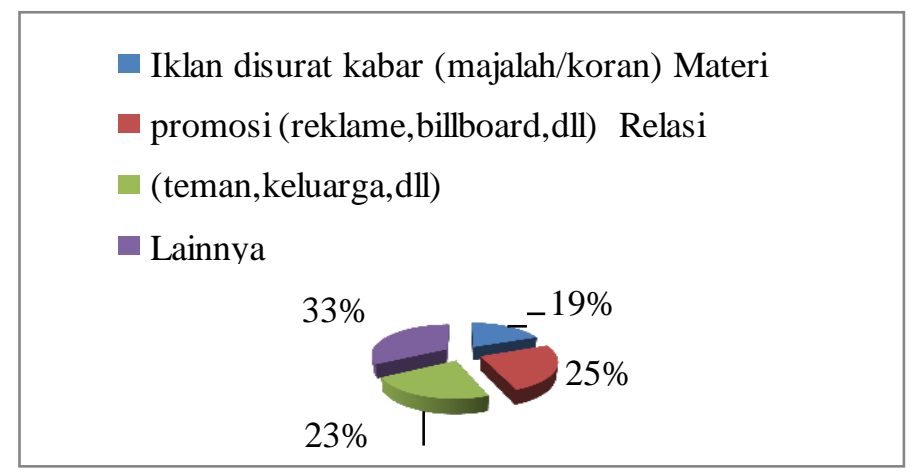

Gambar 4: Perilaku Responden Berdasarkan Bagaimana Cara Mengetahui Tentang Butik Meccanism

Sumber: Olahan Data Peneliti

Menurut gambar 4 menjelaskan perilaku responden Butik Meccanism berdasarkan dari sumber manakah responden mendapatkan sumber tentang butik Meccanism. Hasil terbanyak ternyata responden mendapatkan sumber tentang Butik Meccanism melalui lainnya yaitu sebesar 33\% , maksud lainnya disini mungkin responden mengetahui tentang Butik Meccanism melalui social media baik itu melalui instagram, facebook, twitter ataupun melalui word of mouth. Selanjutnya nilai terbanyak adalah sebesar 25\% dimana responden mendapatkan sumber tentang Meccanism melalui materi promosi seperti reklame, billboard dan lainnya.



Gambar 5: Perilaku Responden Berdasarkan Siapa Yang Mempengaruhi Dalam 
Pembelian Produk Meccanism

Sumber: Olahan Data Peneliti

Melihat gambar 5 menerangkan perilaku reponden Butik Meccanism berdasarkan tentang siapa yang mempengaruhi dalam pembelian produk Meccanism, sebesar $73 \%$ ternyata responden menjawab inisiatif sendiri, dikarenakan terkadang seseorang membeli suatu produk yang diinginkan dikarenakan sesuai seleranya dan merasa cocok pada produk tersebut, atau mungkin kebetulan seseorang itu memang membutuhkan produk tersebut dan kemudian membelinya dan lain sebagainya. Selanjutnya nilai terbanyak adalah dipengaruhi oleh teman atau kenalan dengan nilai sebesar $18 \%$. Selanjutnya responden menjawab dipengaruhi oleh keluaraga dengan nilai sebesar $6 \%$. Terakhir responden menjawab lainnya dengan nilai sebesar $3 \%$.

\subsection{Analisis Data}

Analisis data dalam penelitian ini menggunakan metode Structural Equation Modelling (SEM). Dalam SEM ada beberapa tahapan yang harus dilakukan. Tahapantahapan tersebut diuraikan sebagai berikut :

\section{Uji Validitas}

Menurut Sugiyono (2016) validitas merupakan derajat ketepatan antara data yang terjadi pada obyek penelitian dengan daya yang dapat dilaporkan oleh peneliti. Validitas menunjukkan sejauh mana suatu alat pengukur mengukur apa yang ingin diukur. Dalam hal ini, akan diukur validitas kuesioner sebagai alat pengukur yang telah disusun dimana faktor yang mempengaruhi validitas yang akan diperhitungkan hanya yang menyangkut alat pengukur saja. Uji validitas digunakan untuk mengetahui kevalidan dalam mengumpulkan data. Uji validitas dilakukan dengan rumus kerelasi brivariate person dengan alat bantu SPSS versi 23. Item kuesioner dalam uji validitas dikatakan valid jika nilai rxy > rtabel pada nilai signifikan $5 \%$.

\begin{tabular}{|l|l|l|l|}
\hline \multicolumn{1}{|c|}{ Indikator } & Rhitung & $\begin{array}{c}\text { Rtabel } \\
(\mathbf{n = 9 8} \\
\mathbf{\alpha = 5 \%}\end{array}$ & $\begin{array}{c}\text { Keterang } \\
\text { an }\end{array}$ \\
\hline Sincerity & 0,686 & 0,195 & Valid \\
\hline Excitement & 0,747 & 0,195 & Valid \\
\hline
\end{tabular}

Tabel 2: Uji Validitas

\begin{tabular}{|l|l|l|l|}
\hline Competence & 0,833 & 0,195 & Vaid \\
\hline Sophistication & 0,667 & 0,195 & Valid \\
\hline $\begin{array}{l}\text { Brand } \\
\text { reability }\end{array}$ & 0,824 & 0,195 & Valid \\
\hline $\begin{array}{l}\text { Brand } \\
\text { intention }\end{array}$ & 0,767 & 0,195 & Valid \\
\hline Keputusan & 0,812 & 0,195 & Valid \\
\hline
\end{tabular}




\begin{tabular}{|l|l|l|l|}
\hline pembelian 1 & & & \\
\hline $\begin{array}{l}\text { Keputusan } \\
\text { pembelian 2 }\end{array}$ & 0,664 & 0,195 & Valid \\
\hline $\begin{array}{l}\text { Keputusan } \\
\text { pembelian 3 }\end{array}$ & 0,662 & 0,195 & Valid \\
\hline $\begin{array}{l}\text { Keputusan } \\
\text { pembelian 4 }\end{array}$ & 0,750 & 0,195 & Valid \\
\hline $\begin{array}{l}\text { Keputusan } \\
\text { pembelian 5 }\end{array}$ & 0,791 & 0,195 & Valid \\
\hline
\end{tabular}

Sumber: Olahan Data Peneliti

Hasil perhitungan validitas di atas menunjukkan bahwa 11 indikator dikatakan valid. Untuk jumlah responden $(\mathrm{N})$ sebanyak 100, maka jalur yang dilihat adalah baris ke 100- 2 = 98 dan digunakan taraf signifikan 5\% maka diperoleh rtabel $=0,195$

\section{Uji Reliabilitas}

Menurut Mardapi (2012), reliabilitas atau keandalan adalah koefisien yang menunjukkan tingkat keajegan atau konsisten hasil pengukuran suatu tes. Setiap alat pengukur seharusnya memiliki kemampuan untuk memberikan hasil pengukuran yang konsisten. Uji reliabilitas dilakukan dengan menggunakan rumus alpha. Uji signifikan dilakukan pada taraf $\alpha=0,05$. Instrumen dapat dikatakan reliabel, jika nilai alpha lebih besar dari rtabel $(0,195)$

Tabel 3: Uji Reliabilitas

\begin{tabular}{|l|l|l|}
\hline Alpha & Rtabel & Keterangan \\
\hline 0,913 & 0,195 & Reliabel \\
\hline \multicolumn{3}{|c|}{ Sumber: Olahan Data Peneliti }
\end{tabular}

Hasil uji reliabilitas diperoleh nilai koefisien sebesar 0,913.Berdasarkan nilai koefisien reliabilitas tersebut dapat disimpulkan bahwa semua nilai atau data dalam penelitian ini reliabel atau konsisten, sehingga dapat digunakan sebagai instrument penelitian ini.

\section{Hasil Estimasi Goodness of Fit (GOF) dari model struktural}

Setelah menentukan validitas dan reabilitas, langkah selanjutnya adalah menganalisa kriteria kebaikan fit. Oleh karena itu dalam mengidentifikasikan suatu model, dapat dikatakan baik dan benar, maka peneliti melakukan beberapa analisis mengenai nilainilai yang terkandung dalam model. Model dapat dikatakan bagus dan valid juka memenuhi kebaikan mutlak dan incremental dari fit yang dirangkum dalam tabel berikut 
Tabel 4: Hasil Estimasi Goodness of Fit (GOF)

\begin{tabular}{|c|c|c|c|}
\hline Ukuran GOF & $\begin{array}{l}\text { Target Tingkat } \\
\text { Kecocokan }\end{array}$ & Hasil Estimasi & $\begin{array}{l}\text { Tingkat } \\
\text { Kecocokan }\end{array}$ \\
\hline $\begin{array}{l}\text { X2 (Chi- } \\
\text { square) }\end{array}$ & $\mathrm{P} \geq 0,50$ & 61,734 & Good fit \\
\hline RMSEA & $\begin{array}{l}\text { RMSEA } \\
\leq 0,08\end{array}$ & 0,0762 & Good fit \\
\hline GFI & GFI $>0,80$ & 0,901 & Good fit \\
\hline$\overline{\text { AGFI }}$ & $\begin{array}{l}\text { AGFI } \geq \\
0,90\end{array}$ & 0,828 & Marginalfit \\
\hline $\begin{array}{l}\text { TLI } \\
\text { (NNFI) }\end{array}$ & $\begin{array}{l}\text { TLI }> \\
0,90\end{array}$ & 0,977 & Good fit \\
\hline CFI & $\begin{array}{l}\text { CFI }> \\
0,90\end{array}$ & 0,984 & Good fit \\
\hline NFI & NFI $>0,90$ & 0,960 & Good fit \\
\hline IFI & $\begin{array}{ll}\text { IFI } \quad> \\
0,90\end{array}$ & 0,984 & Good fit \\
\hline RFI & $\begin{array}{ll}\text { RFI } & > \\
0,90 & \end{array}$ & 0,941 & Good fit \\
\hline
\end{tabular}

Sumber : Diolah oleh penulis

Berdasarkan tabel, maka dapat dilihat bahwa hasil estimasi goodness of fit menunjukkan sebagian besar ukuran GOF menunjukkan kecocokan yang baik sehingga dapat disimpulkan bahwa ukuran kecocokan GOF model pengukuran baik.

\section{Analisa Diagram Jalur}

Pada analisis diagram jalur, yang difokuskan adalah kausal diantara variabelvariabel laten. Berikut adalah hasil analisis diagram jalur

Hasil Loading Factor Standardized

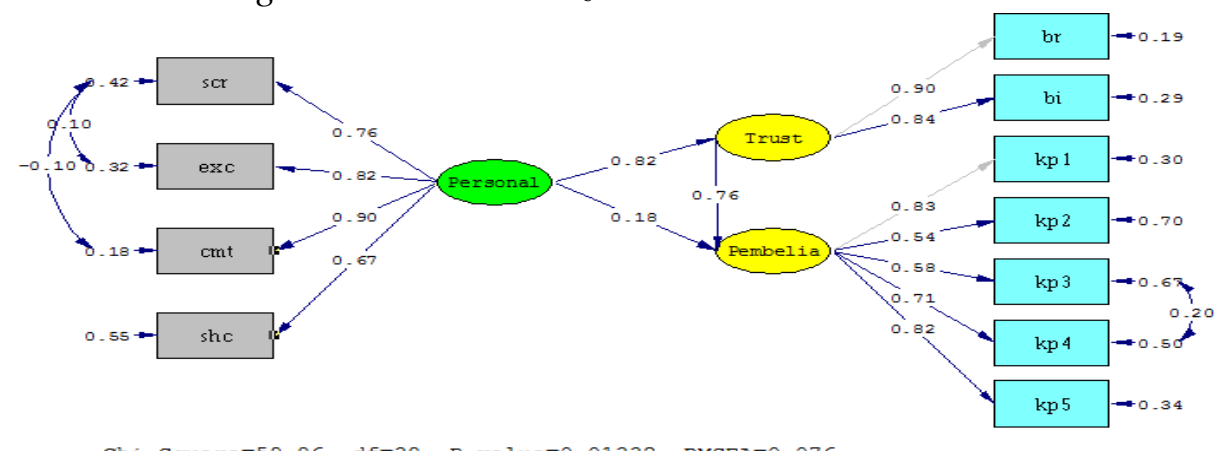

Gambar 6: Model SEM (Standardized Solution)

Sumber : Diolah oleh penulis

Berdasarkan gambar tersebut yang merupakan hasil olah data, Loading factor standardized solution menunjukkan pada variabel laten brand personality bahwa indikator yang paling berpengaruh adalah cmt (competence) sebesar 0,90 dan exc (excitement) sebesar 0,82. Hal ini menunjukkan bahwa Meccanism 
mampu memberikan kesenangan kepada konsumennya dan Meccanism juga mampu untuk menunjukkan keberadaannya dipasar.

Pada variabel brand trust indikator yang paling berpengaruh yaitu brand reability sebesar 0,90. Hal ini menunjukkan bahwa Meccanism mampu memberikan kepercayaan kepada konsumennya yaitu dengan memenuhi semua kebutuhan konsumen dan memberikan kepuasan kepada konsumennya, hal ini juga didukung oleh nilai dari indikator brand intention yang berarti merek Meccanism juga dapat memberikan keyakinan kepada konsumen bahwa merek Meccanism ini mampu untuk mengutamakan kepentingan konsumen ketika konsumen mengalami masalah secara tidak terduga pada produk yang diberikan.

Pada variabel keputusan pembelian indikator yang paling berpengaruh yaitu kp1 (pengenalan kebutuhan) sebesar 0,83. Pada proses keputusan pembelian konsumen mengenali adanya sebuah masalah ataupun sebuah kebutuhan yang dibutuhkannya. Jika kebutuhan tersebut diketahui maka konsumen akan segera memahami tentang sebuah kebutuhan mana yang belum dapat dipenuhi dari tahap inilah proses konsumen untuk membeli sebuah produk yang dibutuhkannya.

Hasil loading factor T-Values adalah sebagai berikut:

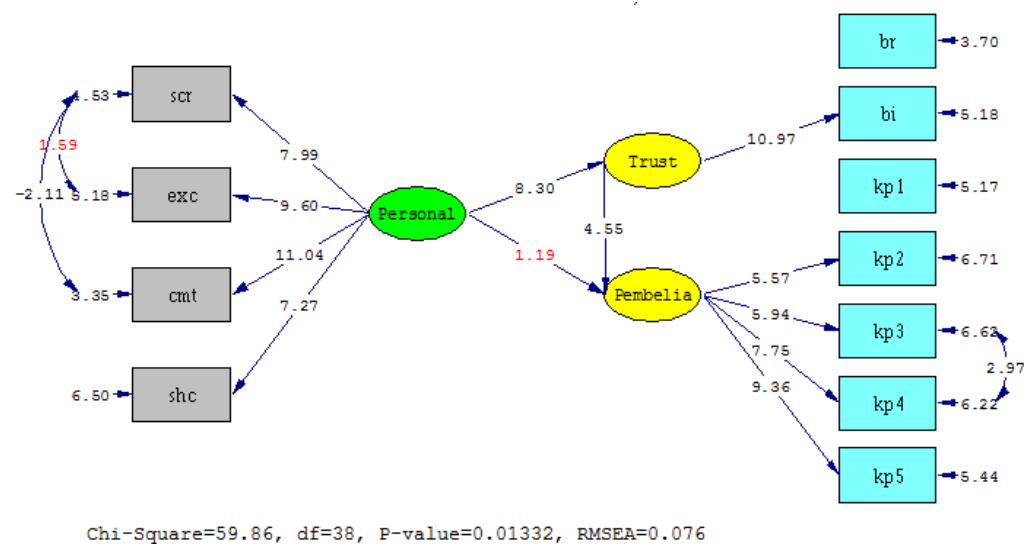

Gambar 7: Model SEM (T-Values)

Sumber: Diolah penulis

Berdasarkan hasil olahan data, t-value variabel brand personality terhadap brand trust adalah 8,30. Kemudian, t-value variabel brand trust terhadap keputusan pembelian menunjukkan angka 4,55. Hal ini menunjukkan bahwa t-value > t-tabel $(1,96)$, artinya brand personality terhadap brand trust dan brand trust terhadap keputusan pembelian berpengaruh positif. Sedangkan t-value pada variabel brand personality pada variabel keputusan pembelian menunjukkan angka 1,19 atau t-value berada antara $-1,96$ dan 1,96. Artinya brand personality berpengaruh negatif terhadap keputusan pembelian pelanggan di Butik Mecanism.

\section{Analisa Hipotesis}




\section{Analisa Pengaruh Brand Personality Terhadap Keputusan Pembelian}

Pengaruh total brand personality terhadap keputusan pembelian sebesar 0,18 dan nilai t-valuenya 1,19. Dari nilai pengaruh total dan nilai $t$-value diatas, maka menunjukkan

tolak H1 terima H0. Penerimaan terhadap H0 berarti tidak ada hubungan yang signifikan antara brand personality terhadap keputusan pembelian pelanggan Butik Meccanism. Nilai koefesien estimasi yaitu sebesar 0,18 menunjukkan nilai yang rendah,sehingga menunjukkan bahwa brand personality tidak memiliki pengaruh signifikan terhadap keputusan pembelian pelanggan Butik Meccanism.

Dengan ditolaknya hipotesis pengaruh brand personality terhadap keputusan pembelian, maka hasil ini didukung oleh penelitian terdahulu yang dilakukan oleh Siregar (2015) yang berjudul analisa pengaruh brand personality terhadap brand awareness dan perceived quality dalam keputusan pembelian kartu provider xl dikota pekanbaru. Pada hasil penelitian tersebut menunjukkan bahwa brand personality tidak berpengaruh terhadap keputusan pembelian dan harus menggunakan variabel mediasi. Hal ini dibuktikan oleh hasil $t-$ value dari indikator she (sophistication) yaitu sebesar 7,27 dan scr (sincerity) yaitu sebesar 7,99 yang merupakan nilai terendah dari variabel brand personality. Sophistication ini merupakan dimensi kepribadian pembentuk pengalaman yang memuaskan. Dikarenakan sebagian besar konsumen Meccanism belum merasakan kepuasan dari produk yang ditawarkan Meccanism, dan indikator ini didukung oleh indikator sincerity dimana produk Meccanism belum dapat memenuhi kebutuhan, keinginan dan harapan konsumen. Hal ini dapat disimpulkan bahwa brand personality belum secara langsung berpengaruh terhadap keputusan pembelian pada produk Meccanism.

\section{Analisa Pengaruh Brand Personality Terhadap Brand Trust}

Pengaruh total brand personality terhadap brand trust pelanggan sebesar 0,82 dan nilai t-value nya adalah 8,30 . Dari nilai pengaruh total dan nilai t-value diatas, maka menunjukkan tolak H0 terima H1. Penerimaan terhadap H1 berarti ada hubungan yang signifikan antara brand personality terhadap brand trust pelanggan Butik Meccanism. Nilai koefesien estimasi yaitu 0,82, hal ini menunjukkan nilai

positif yang tinggi, sehingga menunjukkan bahwa brand personality adalah 0,82 signifikan positif terhadap brand trust pelanggan Butik Meccanism.

Dengan diterimanya hipotesis pengaruh brand personality terhadap brand trust, maka hasil ini mendukung penelitian yang dilakukan oleh Sabrina (2011) dengan judul 
pengaruh brand personality pada brand trust, brand attachment, brand commitment, dan brand loyalty. Pada hasil penelitian tersebut menunjukkan bahwa brand personality berpengaruh terhadap brand trust. Saat konsumen merasa sebuah merek memiliki kepribadian yang sama dengan dirinya, konsumen akan percaya bahwa merek tersebut dapat membangun dan mempertahankan identitas mereka. Saat suatu merek memiliki brand personality yang baik, konsumen juga akan percaya bahwa merek tersebut dapat menjadi simbol dari identitas sekaligus dapat difungsikan untuk mengekspresikan diri mereka. Hal tersebut dikarenakan jika suatu merek yang memiliki brand personality yang baik, dapat memunculkan kepercayaan konsumen pada merek tersebut, konsumen memanfaatkan merek untuk membangun dan mempertahankan identitas diri mereka (Bouhlel et al.,2009).

\section{Analisa Pengaruh Brand Trust Terhadap Keputusan Pembelian}

Pengaruh total brand trust terhadap keputusan pembelian pelanggan Butik Meccanism sebesar 0,76 dan nilai t-value nya adalah 4,55. Dari nilai pengaruh total dan nilai t- value diatas, maka menunjukkan tolak H0 terima H1. Penerimaan terhadap H1 berarti ada hubungan yang signifikan antara brand trust dan keputusan pembelian pelanggan Butik Meccanism. Nilai koefisien estimasi yaitu sebesar 0,76, hal ini menunjukkan nilai positif yang tinggi, sehingga menunjukkan bahwa brand trust signifikan terhadap keputusan pembelian pelanggan Butik Meccanism.

Dengan diterimanya hipotesis pengaruh brand trust terhadap keputusan pembelian, maka hasil ini mendukung penelitian Wilujeng (2015) yang berjudul pengaruh brand awareness dan brand trust terhadap keputusan pembelian produk oriflame. Pada hasil penelitian tersebut menunjukkan bahwa brand trust berpengaruh terhadap keputusan pembelian. Hasil penelitian ini didukung oleh teori dari Gurves dan Kocia yang mengatakan bahwa kepercayaan pada sebuah merek merupakan hal yang dapat mempengaruhi perilaku konsumen kepada suatu merek dan pada perusahaan yang menghasilkannya (Gurves dan Kocia,2003). Kepercayaan merek yang baik dan kuat dari konsumen akan menciptakan keputusan pembelian terhadap merek tersebut.

\section{Analisa Pengaruh Brand personality Terhadap Keputusan Pembelian Melalui Brand Trust}

Pengaruh total brand personality terhadap keputusan pembelian melalui brand trust Butik Meccanism sebesar 0,62 dan nilai t- valuenya adalah 4,13. Dari nilai pengaruh total dan nilai $\mathrm{t}$-value diatas, maka menunjukkan tolak $\mathrm{H} 0$ terima H1. Penerimaan terhadap $\mathrm{H} 1$ berarti ada hubungan yang signifikan antara brand personality terhadap keputusan pembelian melalui brand trust Butik Meccanism. Nilai koefesien estimasi yaitu sebesar 0,62 , hal ini menunjukkan nilai positif yang tinggi, sehingga menunjukkan bahwa brand personality signifikan terhadap keputusan pembelian melalui brand trust pelanggan butik Meccanism.

Dengan diterimanya hipotesis pengaruh pada brand personality terhadap 
keputusan pembelian melalui brand trust, maka hasil ini serupa dengan hasil penelitian Fadhillah (2015) yang berjudul pengaruh brand personality terhadap purchase intention dengan brand trust sebagai variabel mediasi (studi pada running shoes merek Nike). Pada hasil tersebut menunjukkan bahwa brand personality memiliki pengaruh tidak langsung yang signifikan terhadap purchase intention melalui brand trust. Hasil penelitian tersebut juga sejalan dengan penelitian yang dilakukan oleh Bouhlel (2009) yang menyatakan bahwa dalam menentukan merek mana yang akan digunakan, konsumen akan melakukan proses evaluasi terlebih dahulu yaitu salah satunya melalui kepribadian yang melekat pada merek tersebut. Kepercayaan konsumen akan lebih tinggi ketika mereka merasa ketika kepribadian merek sesuai dengan apa yang mereka harapkan. Sehingga pada akhirnya hal tersebut akan menimbulkan minat beli konsumen.

\section{Kesimpulan Dan Saran \\ 5.1 Kesimpulan}

Berdasarkan hasil analisis data, maka diperoleh kesimpulan sebagai berikut:

1. Brand personality memiliki pengaruh positif terhadap brand trust. Dengan kata lain, jika merek Meccanism memiliki brand personality yang baik maka akan menimbulkan sebuah kepercayaan konsumen Butik Meccanism terhadap merek Meccanism tersebut.

2. Brand trust ditemui memiliki pengaruh positif terhadap keputusan pembelian. Dengan kata lain, jika merek Meccanism memiliki kepercayaan merek yang baik dan kuat dari seorang konsumen maka dapat menciptakan keputusan pembelian konsumen terhadap merek Meccanism tersebut.

3. Pada penelitin ini juga ditemukannya pengaruh brand personality terhadap keputusan pembelian melalui brand trust dan mendapatkan hasil positif dimana brand personality akan berpengaruh terhadap keputusan pembelian ketika ditambahkan variabel mediasi yaitu variabel brand trust.

4. Berbeda halnya dengan brand personality yang ditemui oleh peneliti, dimana peneliti mendapatkan hasil bahwa brand personality tidak memiliki pengaruh positif terhadap keputusan pembelian. Hasil yang didapat ini tidak sesuai dengan hipotesis dalam model penelitian.

\subsection{Saran}

Berdasarkan kesimpulan yag didapat dalam penelitian ini, maka penulis menyampaikan beberapa saran bagi pihak-pihak yang terkait dalam penelitian ini antara lain sebagai berikut :

1. Dari hasil yang dapat diketahui bahwa pelanggan tidak secara langsung untuk membeli produk hanya karena kepribadian merek saja dengan demikian diharapkan butik Meccanism tidak hanya fokus dalam membangun karakteristik mereknya akan tetapi juga harus fokus dalam memperoleh kepercayaan konsumen yaitu dengan 
memberikan service excellent, dikarenakan keputusan pembelian dapat terjadi apabila terdapat kepercayaan dari suatu konsumen, sehingga dapat menciptakan kepuasan bagi konsumen saat membeli produk Meccanism.

2. Selain itu untuk dapat meningkatkan kepercayaan konsumen butik Meccanism diharapkan dapat lebih meningkatkan konsistennya dalam memenuhi segala kebutuhan dan keinginan responden, dan juga diharapkan untuk bisa memberikan kesenangan untuk para pemakai produk Meccanism itu sendiri dengan cara memberikan kualitas produk yang baik agar bisa meningkatkan keputusan pembelian pada Butik Mecccanism.

3. Berdasarkan hasil yang didapat menyatakan bahwa merek Meccanism selalu menjaga konsistensi dalam berinovasi pada produk yang akan ditawarkan. Sehingga dapat menarik konsumen dalam melakukan pembelian pada produk Meccanism.

\section{Referensi}

Aaker, J. L. (1997). Dimensions of Brand Personality . Journal of Marketing Research, , 347.

Ainy. (2015). Konstruksi Busana Muslimah Zaskia Adya Mecca di Instagram .

Armstrong, G. (2008). Prinsip prinsip pemasaran. Jakarta: Erlangga. 